\title{
PENGARUH PENDAPATAN ASLI DAERAH (PAD), DANA ALOKASI UMUM (DAU), DAN DANA ALOKASI KHUSUS (DAK) PADA PERTUMBUHAN EKONOMI DAERAH PROVINSI SULAWESI UTARA
}

\author{
Virginia Laloan \\ O. Esry H. Laoh \\ Caroline B. D. Pakasi
}

\begin{abstract}
This study aims to examine the effect of original income, general allocation funds and special allocation funds to regional economic growth in North Sulawesi Province. This research was conducted for three months starting from October until December 2017 in North Sulawesi Province. In this study the data used are secondary data obtained from the Central Bureau of Statistics (BPS) of North Sulawesi Province. The date is processed using analyzed by using multiple linear regression research method and presented in tabular form. The result of the research shows that the local revenue (PAD) significantly influences economic growth, but negatively impacts the economic growth in north Sulawesi, the general allocation fund (DAU) has a significant effect and has a positive effect on economic growth in North Sulawesi Province and The Special Allocation Fund (DAK), shows that there is no significant effect on economic growth in the Province of North Sulawesi.
\end{abstract}

Keywords: economic growth, locally-generated revenue, general allocation funds, special allocation funds, North Sulawesi Province.

\begin{abstract}
ABSTRAK
Penelitian ini bertujuan untuk menguji pengaruh pendapatan asli daerah, dana alokasi umum dan dana alokasi khusus terhadap pertumbuhan ekonomi daerah di Provinsi Sulawesi Utara. Penelitian ini dilakukan selama tiga bulan mulai pada bulan Oktober hingga bulan Desember 2017 di Provinsi Sulawesi Utara. Pada penelitian ini data yang digunakan adalah data sekunder yang diperoleh dari Badan Pusat Statistik (BPS) Provinsi Sulawesi Utara. Data tersebut diolah menggunakan metode regresi linear berganda dan disajikan dalam bentuk tabel. Hasil penelitian menunjukan bahwa Pendapatan Asli Daerah (PAD) berpengaruh secara signifikan terhadap pertumbuhan ekonomi, tetapi mengalami pengaruh negatif terhadap pertumbuhan ekonomi di Sulawesi Utara, Dana Alokasi Umum (DAU) berpengaruh secara signifikan dan berpengaruh positif mengalami peningkatan terhadap pertumbuhan ekonomi di Provinsi Sulawesi Utara dan Dana Alokasi Khusus (DAK), menunjukan bahwa tidak terdapat pengaruh secara signifikan terhadap pertumbuhan ekonomi di Provinsi Sulawesi Utara.
\end{abstract}

Kata kunci: pertumbuhan ekonomi, pendapatan asli daerah, dana alokasi umum, dana alokasi khusus, Provinsi Sulawesi Utara. 


\section{PENDAHULUAN}

\section{Latar Belakang}

Pembangunan infrastruktur dan pemberian berbagai fasilitas dilakukan untuk meningkatkan daya tarik investasi. Pembangunan infrastruktur industri mempunyai dampak yang nyata terhadap kenaikan Pendapatan Asli Daerah (PAD). Dalam pelaksanaan kewenangan Pemerintahaan Daerah, Pemerintahan Pusat akan memberikan dana perimbangan yang terdiri dari Dana Alokasi Umum (DAU), Dana Alokasi Khusus (DAK). Kebijakan penggunaan semua dana tersebut diserahkan kepada Pemerintah Daerah.

Dalam upaya peningkatan kemandirian daerah, Pemda dituntut untuk mengoptimalkan potensi pendapatan yang lebih besar untuk pembangunan pada sektorsektor yang produktif di daerah. Provinsi Sulawesi Utara adalah merupakan daerah yang memiliki potensi pendapatan asli daerah, sehingga diharapkan seluruh daerah kabupaten di Provinsi Sulawesi Utara dapat mandiri dalam memenuhi kebutuhan seluruh kabupaten.

Realisasi APBD terdiri dari pendapatan asli daerah, dana perimbangan, dan pendapatan lainnya. Pendapatan asli daerah terdiri dari pajak, retribusi, hasil pengelolaan kekayaan daerah dan lain-lain. Sedangkan dana perimbangan terdiri dari DAU, DAK, dan dana bagi hasil. Dari data Badan Pusat Statistik (BPS) Realisasi APBD Provinsi Sulawesi Utara tahun anggaran 2003-2016 cenderung meningkat, namun jika dilihat pertumbuhan ekonomi mengalami fluktuatif dimana pada tahun 2002 sampai tahun 2009 terjadi peningkatan $3,19 \%$ menjadi $7,84 \%$ tapi kemudian turun pada tahun 2010 menjadi 7,15\% kemudian naik di tahun 2011 sebesar 7,39\% dan 2012 Sebesar 7,85\% kemudian di tahun 2013 pertumbuhan ekonomi mencapai $7,44 \%$ dan turun di tahun 2014 menjadi $6,34 \%$ dan di akhir penelitian pertumbuhan ekonomi mencapai $6,27 \%$. Sedangkan pertumbuhan ekonomi tertinggi terjadi di tahun 2012 sebesar 7,85\%. Dengan rata-rata pertumbuhan ekonomi Sulawesi Utara 6,3\% keadaan ini yang membuat penulis tertarik untuk mengetahui seberapa besar pengaruh PAD, DAU, dan DAK terhadap pertumbuhan ekonomi di Provinsi Sulawesi Utara.

\section{Perumusan Masalah}

Oleh karena itu, diajukan beberapa rumusan permasalahan yang akan diteliti dan dibahas, yaitu:

1. Apakah Dana Alokasi Umum (DAU) berpengaruh terhadap pertumbuhan ekonomi di Provinsi Sulawesi Utara?

2. Apakah Dana Alokasi Khusus (DAK) berpengaruh terhadap pertumbuhan ekonomi di Provinsi Sulawesi Utara ?

3. Apakah Pendapatan Asli Daerah (PAD) berpengaruh terhadap pertumbuhan ekonomi di Provinsi Sulawesi Utara?

\section{Tujuan Penelitian}

Penelitian ini bertujuan untuk :

1. Menguji pengaruh Dana Alokasi Umum (DAU) terhadap pertumbuhan ekonomi.

2. Menguji pengaruh Dana Alokasi Khusus (DAK) terhadap pertumbuhan ekonomi.

3. Menguji pengaruh Pendapatan Asli Daerah (PAD) terhadap pertumbuhan ekonomi.

\section{Manfaat Penelitian} untuk :

Kegunaan penelitian ini bermanfaat

1. Bagi Pemerintah Provinsi Sulawesi Utara sebagai sumber informasi tentang pentingnya mengoptimalkan potensi daerah yang dimiliki guna untuk meningkatkan kualitas layanan publik demi kemajuan daerah.

2. Bagi peneliti sebagai suatu analisis untuk mengetahui pertumbuhan ekonomi daerah serta hubungan keuangan antara pemerintah pusat dengan pemerintah daerah beserta pengelolaan keuangan daerah yang berkaitan dengan pengembangan daerah. 


\section{METODOLOGI PENELITIAN}

\section{Waktu dan Tempat Penelitian}

Penelitian ini dilaksanakan di Provinsi Sulawesi Utara selama tiga bulan dari bulan Oktober sampai bulan Desember 2017.

\section{Metode Pengumpulan Data}

Data yang digunakan dalam penelitian ini adalah data sekunder, yaitu data yang diperoleh dari Badan Pusat Statistik berupa data PDRB dan data APBD Provinsi Sulawesi Utara yang terdiri dari realisasi PAD, DAU, DAK dan pertumbuhan ekonomi pada tahun 2003-2016.

\section{Operasional Variable dan Konsepsi Pengukuran Variabel}

Operasional Variabel dan Pengukuran Variabel Untuk memberikan pemahaman yang lebih spesifik terhadap variabel penelitian, maka variabel - variabel tersebut didefinisikan secara operasional dan diukur sebagai berikut:

1. Pertumbuhan ekonomi adalah perkembangan kegiatan dalam perekonomian yang menyebabkan barang dan jasa yang diproduksi dalam masyarakat bertambah dan kemakmuran masyarakat meningkat. Pertumbuhan ekonomi diukur dari selisih antara Pendapatan Domestik Regional Bruto (PDRB) pada saat ini dengan PDRB sebelumnya dibagi dengan PDRB saat ini. $\mathrm{Y}=$ Pertumbuhan Ekonomi (\% / Tahun).

2. Pendapatan Asli Daerah (PAD) adalah penerimaan yang diperoleh daerah dari sumber-sumber dalam wilayahnya sendiri yang dipungut berdasarkan peraturan daerah sesuai dengan peraturan perundangundangan yang berlaku. PAD diukur dari total penerimaan pajak daerah, retribusi daerah, hasil perusahaan milik daerah dan hasil pengelolaan kekayaan daerah yang dipisahkan dan lain-lain PAD yang sah di Sulawesi Utara. X1= Pendapatan Asli Daerah (Rp / Tahun).

3. Dana Alokasi Umum (DAU) adalah dana yang berasal dari Anggaran Pendapatan dan Belanja Negara (APBN) yang dialokasikan dengan tujuan pemerataan kemampuan keuangan antar daerah untuk membiayai kebutuhan pengeluarannya dalam rangka pelaksanaan desentralisasi. DAU diukur dari jumlah penerimaan yang diberikan oleh pemerintah pusat di Sulawesi Utara. X2 = Dana Alokasi Umum (Rp / Tahun).

4. Dana Alokasi Khusus (DAK) adalah dana yang berasal dari APBN yang dialokasikan kepada daerah untuk membantu membiayai kebutuhan khusus. DAK ditikur dari jumlah penerimaan DAK yang diberikan oleh pemerintah pusat di Sulawesi Utara. X3 = Dana Alokasi Khusus (Rp / Tahun).

\section{Analisis Data}

Metode analisis data dalam penelitian ini menggunakan analisis regresi linier berganda untuk mengetahui pengaruh antara lebih dari satu variabel terhadap variabel lainya dan mengetahui signifikan antara variabel bebas terhadap variabel terikat.

Rumus analisis regresi linier berganda yakni:

$\mathrm{Y}=\beta 0+\beta 1 \mathrm{X} 1+\beta 2 \mathrm{X} 2+\beta 3 \mathrm{X} 3+\varepsilon$

Dimana :

$\mathrm{Y}=$ Pertumbuhan Ekonomi $(\%)$

$\beta 0=$ Konstanta

$\beta 1, \beta 2, \beta 3=$ Koefesien regresi

$\mathrm{X} 1 \quad=$ Pendapatan Asli Daerah (Rp)

$\mathrm{X} 2=$ Dana Alokasi Umum (Rp)

$\mathrm{X} 3=$ Dana Alokasi Khusus (Rp)

$\varepsilon \quad=$ Residual

Hipotesis :

1. Diduga Pendapatan Asli Daerah (PAD) berpengaruh terhadap pertumbuhan ekonomi

$\mathrm{H} 0: \beta 1=0$

$\mathrm{H} 1: \beta 1 \neq 0$

2. Diduga Dana Alokasi Umum (DAU) berpengaruh terhadap pertumbuhan ekonomi

$\mathrm{H} 0: \beta 2=0$

$\mathrm{H} 1: \beta 2 \neq 0$

3. Diduga Dana Alokasi Khusus (DAK) berpengaruh terhadap pertumbuhan ekonomi

$\mathrm{H} 0: \beta 3=0$

$\mathrm{H} 1: \beta 3 \neq 0$ 
Jika :

- H0 di tolak dan H1 diterima maka $\beta 1$ atau $\beta 2$ atau $\beta 3 \neq 0$ berarti, $\mathrm{X} 1$ atau $\mathrm{X} 2$ atau $\mathrm{X} 3$ berpengaruh pada pertumbuhan ekonomi.

- H0 di terima dan H1 di tolak maka $\beta 1$ atau $\beta 2$ atau $\beta 3=0$ berarti, $X 1$ atau $X 2$ atau X3 tidak berpengaruh pada pertumbuhan ekonomi.

\section{HASIL DAN PEMBAHASAN}

\section{Gambaran Umum Provinsi Sulawesi Utara}

Berdasarkan posisi geografisnya, Provinsi Sulawesi Utara terletak di Jazirah Utara Pulau Sulawesi dan merupakan salah satu dari tiga Provinsi di Indonesia yang terletak di sebelah utara garis khatulistiwa. Dilihat dari letak geografis Provinsi Sulawesi Utara terletak pada $0^{\circ} \mathrm{LU}-3^{\circ} \mathrm{LU}$ dan $123^{\circ} \mathrm{BT}-126^{\circ} \mathrm{BT}$. Iklim daerah Sulawesi Utara termasuk tropis dan curah hujan tidak merata. Suhu udara berada pada setiap tingkat ketinggian makin ke atas makin sejuk seperti daerah Kota Tomohon, Langowan di Minahasa, Modoinding di Kabupaten Minahasa Selatan, Kota Kotamobagu, Modayag dan Pasi di Kabupaten Bolaang Mongondow. Daerah yang paling banyak menerima curah hujan adalah daerah Minahasa. Suhu atau temperature dipengaruhi pula oleh ketinggian tempat di atas permukaan laut. Semakin tinggi letaknya, maka semakin rendah pula suhunya, dengan perhitungan setiap kenaikan 100 meter dapat menurunkan suhu sekitar $0,6^{\circ} \mathrm{C}$.

Luas Wilayah Sulawesi Utara tercatat $13,850 \mathrm{~km}^{2}$ yang terbagi atas 11 Kabupaten dan 4 Kota. Jumlah penduduk di wilayah Provinsi Sulawesi Utara pada tahun 2016 adalah 2.436.921 jiwa di wilayah Kabupaten dan Kota di Provinsi Sulawesi Utara, dimana jumlah penduduk terbanyak berada di wilayah Kota Manado dengan jumlah 427.906 jiwa, yang kemudian diikuti oleh jumlah penduduk di wilayah Kabupaten Minahasa dengan jumlah 332.190 jiwa. Sedangkan jumlah penduduk tersedikit berada di wilayah Bolaang Mongondow Timur dengan jumlah 68.692 jiwa, yang disusul oleh jumlah penduduk di wilayah
Kabupaten Bolaang Mongondow Selatan dengan jumlah 63.207 jiwa.

Hal ini bisa menjadi pertumbuhan ekonomi yang terus berkembang di Sulawesi Utara hal ini dapat dilihat pada Gambar 1.

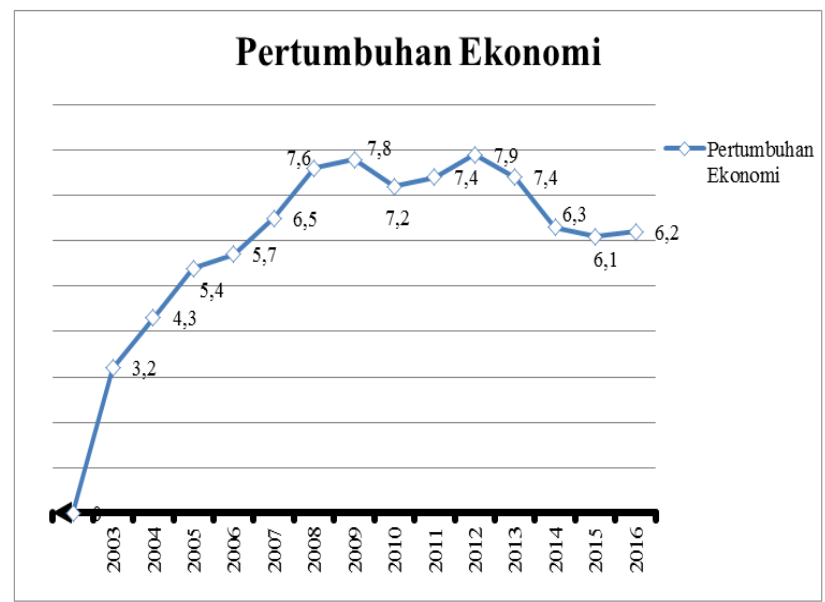

Gambar 1. Pertumbuhan ekonomi Sulawesi Utara tahun 2003-2016

Dari gambar 1. diatas dapat dilihat bahwa pertumbuhan ekonomi Sulawesi Utara mengalami fluktuasi dari tahun ke tahun. Dari tahun 2003 sampai tahun 2009 terjadi peningkatan dari $3,19 \%$ menjadi $7,84 \%$ lalu kemudian turun pada tahun 2010 menjadi 7,15\% kemudian naik di tahun 2011 sebesar 7,39\% dan 2012 Sebesar 7,85\% kemudian di tahun 2013 pertumbuhan ekonomi mencapai 7,44\% dan turun di tahun 2014 menjadi 6,34\% dan di akhir penelitian pertumbuhan ekonomi mencapai $6,27 \%$. Sedangkan pertumbuhan ekonomi tertinggi terjadi di tahun 2012 sebesar $7,85 \%$. Suatu perekonomian dikatakan mengalami pertumbuhan ekonomi jika jumlah produksi barang dan jasanya meningkat. Pertumbuhan ekonomi merupakan masalah perekonomian jangka panjang dan menjadi kenyataan yang selalu dialami oleh suatu bangsa.

\section{Hasil Analisis}

Berdasarkan data Badan Pusat Statistik Sulawesi Utara mengenai Laporan Realisasi Anggaran Pendapatan untuk informasi Pendapatan Asli Daerah (PAD), Dana Alokasi Umum (DAU) dan Dana Alokasi Khusus (DAK), serta data Pertumbuhan Ekonomi Provinsi Sulawesi Utara tahun 2003-2016 sebagai berikut: 


\begin{tabular}{|c|c|c|c|c|}
\hline \multirow{2}{*}{$\begin{array}{l}\text { Tabel } 1 . \\
\text { Tahun }\end{array}$} & \multicolumn{4}{|c|}{$\begin{array}{l}\text { Realisasi Pendapatan Asli Daerah, Dana Alokasi Umum, Dan } \\
\text { Alokasi Khusus, (ribuan rupiah) terhadap Pertumbuhan Ekonomi } \\
\text { (\%) Provinsi Sulawesi Utara Tahum 2003-2016 }\end{array}$} \\
\hline & $\mathrm{Y}(\mathrm{Pe})$ & $\mathrm{X} 1(\mathrm{Pad})$ & X2 (Dau) & X3 (Dak) \\
\hline 2003 & 3.2 & 119.691 .244 & 242.328 .520 & 6.700 .000 \\
\hline 2004 & 4.3 & 147.139 .838 & 220.626 .000 & 58.520 .641 \\
\hline 2005 & 5.4 & 198.270 .258 & 247.873 .000 & 26.053 .060 \\
\hline 2006 & 5.7 & 211.236 .498 & 404.324 .000 & 300.569 .950 \\
\hline 2007 & 6.5 & 252.324 .235 & 447.094 .538 & 486.522 .000 \\
\hline 2008 & 7.6 & 322.580 .793 & 532.916 .167 & 28.079 .000 \\
\hline 2009 & 7.8 & 331.083 .668 & 558.634 .931 & 52.879 .000 \\
\hline 2010 & 7.2 & 418.737 .661 & 558.781 .013 & 17.439 .200 \\
\hline 2011 & 7.4 & 535.087 .975 & 619.711 .007 & 29.288 .200 \\
\hline 2012 & 7.9 & 633.650 .533 & 790.534 .491 & 43.539 .930 \\
\hline 2013 & 7.4 & 789.631 .755 & 885.684 .277 & 54.346 .140 \\
\hline 2014 & 6.3 & 937.681 .927 & 949.852 .622 & 59.675 .060 \\
\hline 2015 & 6.1 & 1.012 .945 .961 & 1.026 .948 .809 & 76.744 .790 \\
\hline 2016 & 6.2 & 1.141 .321 .190 & 1.065 .545 .204 & 668.226 .132 \\
\hline Jumlah & 88.8 & 7.051 .383 .536 & 8.550 .854 .579 & 1.908 .583 .103 \\
\hline Ratarata & 6.3 & 5.036 .702 .526 & 6.107 .753 .271 & 1.363 .273 .645 \\
\hline
\end{tabular}

Berdasarkan Tabel 1. menunjukkan bahwa pertumbuhan ekonomi Sulawesi Utara mengalami fluktuasi dari tahun ke tahun. Dari tahun 2003 sampai tahun 2009 terjadi peningkatan dari $3,19 \%$ menjadi $7,84 \%$ lalu kemudian turun pada tahun 2010 menjadi $7,15 \%$ kemudian naik di tahun 2011 sebesar 7,39\% dan 2012 Sebesar 7,85\% kemudian di tahun 2013 pertumbuhan ekonomi mencapai $7,44 \%$ dan turun di tahun 2014 menjadi $6,34 \%$ dan di akhir penelitian pertumbuhan ekonomi mencapai $6,27 \%$. Sedangkan pertumbuhan ekonomi tertinggi terjadi di tahun 2012 sebesar 7,85\%. Dengan rata-rata pertumbuhan ekonomi Sulawesi Utara 5,92\%. Sedangkan Dana Alokasi Umum (DAU), menunjukkan di Sulawesi Utara pada tahun 2003 yaitu 242,328,520. Dan terjadi penurunan pada tahun 2004 menjadi 220,626,000. Tetapi pada tahun 2005 terjadi peningkatan sebesar $247,873,000$. Dan terus mengalami peningkatan sampai tahun 2016 sebesar 1.065,545,204. Dan Dana Alokasi Khusus (DAK), menunjukkan bahwa penerimaan daerah yang bersumber dari dana perimbangan yang berupa Dana Alokasi Khusus, mengalami fruktuasi, pada tahun 2003 adalah 6.700.000 dan pada tahun 2004 meningkat sebesar 58.520.641 dan di tahun 2005 menurun menjadi 26.053.060 dan pada tahun 2006 kembali meningkat menjadi 300.569.950 dan di tahun 2007 terus meningkat sebesar 486.522 .000 dan mengalami penurunan di tahun 2008 menjadi 28.079.000. kemudian meningkat di tahun 2009 menjadi 52.879.000 dan pada tahun 2010 kembali menurun menjadi 17.439200 dan pada tahun 2011 meningkat menjadi 29.288.200 dan terus meningkat sampai tahun 2016 sebesar 668.226.132. Berdasarkan penjelasan tersebut akan di uji apakah PAD, DAU, dan DAK, berpengaruh terhadap terhadap Pertumbuhan Ekonomi di Sulawesi Utara.

\section{Uji Regresi Linear Berganda}

Hasil Analisis Regresi Linear Berganda Berdasarkan hasil perhitungan dengan menggunakan bantuan program komputer minitab 17. Diperoleh koefisien regresi seperti dalam tabel berikut:

Tabel 2. Analisis Regresi Pengaruh Regression Analysis: PE Terhadap X1 (PAD), X2 (DAU), X3 (DAK)

\begin{tabular}{lccc}
\hline Coefficients & & & \\
\hline Term & Coef & T-Value & P-Value \\
\hline Constant & 2.628 & 2.93 & 0.015 \\
X1 (PAD) & -0.000011 & -3.36 & 0.007 \\
X2 (DAU) & 0.000016 & 3.93 & 0.003 \\
X3 (DAK) & -0.000001 & -0.45 & 0.665 \\
\hline PE $=2.628-0.000011$ X1 (PAD) + 0.000016 \\
\multicolumn{4}{c}{ X2 (DAU) - 0.000001 X3 (DAK) } \\
\hline
\end{tabular}

Sumber : program komputer minitab 17

Berdasarkan Hasil analisis pada perhitungan Tabel 2. bahwa:

- X1 (PAD), menunjukkan taraf signifikan dilihat dari p sebesar 0.007 .

- X2 (DAU), menunjukkan taraf signifikan dilihat dari p sebesar 0.003 .

- X3 (DAK), menunjukkan tidak signifikan dilihat dari p sebesar 0.665 .

\section{Pembahasan}

Berdasarkan hasil analisis dari minitab 17. Pengaruh pendapatan asli daerah, Dana Alokasi Umum, Dana Alokasi Khusus. Terhadap Pertumbuhan Ekonomi. 


\section{Pengaruh Pendapatan Asli Daerah (PAD) terhadap Pertumbuhan Ekonomi}

Hipotesis 1 : Dilihat dari p-value dengan taraf signifikansi sebesar $0,7 \%$ yaitu lebih kecil dari $\alpha=5 \%$. Menunjukkan bahwa $\mathrm{H}_{0}$ ditolak. Berarti Pendapatan Asli Daerah berpengaruh pada Pertumbuhan Ekonomi. Berarti Besarnya koefisien regresi $\beta 1$ ialah $0,000011 \%$ yang mengartikan bahwa PAD mengalami pengaruh terhadap pertumbuhan ekonomi, tetapi bersifat negatif. Setiap kenaikan 1.000.000.000 (satu milyar rupiah) dari PAD akan diikuti oleh penurunan pertumbuhan ekonomi yaitu $-0,000011 \%$. Dengan demikian bahwa PAD berpengaruh, tetapi mengalami penurunan terhadap pertumbuhan ekonomi. Hal ini terjadi karena Pendapatan Asli Daerah di gunakan lebih kepada biaya operasional yaitu membayar gaji anggota DPRD. Sehingga PAD di Sulawesi Utara belum produktif untuk meningkatkan pertumbuhan ekonomi.

\section{Pengaruh Dana Alokasi Umum (DAU) terhadap pertumbuhan Ekonomi}

Hipotesis 2 : Dilihat dari p-value dengan taraf signifikansi sebesar $0,3 \%$ yaitu lebih kecil dari $\alpha=5 \%$. Menunjukkan bahwa $\mathrm{H}_{0}$ ditolak. Berarti Dana Alokasi Umum berpengaruh pada Pertumbuhan Ekonomi. Besarnya koefisien regresi $\beta 1$ ialah $0,000016 \%$ Mengartikan bahwa DAU berpengaruh positif terhadap Pertumbuhan Ekonomi. Setiap kenaikan DAU sebesar 1.000.000.000 (satu milyar rupiah) dari DAU akan meningkatkan pertumbuhan ekonomi sebesar 0,000016\%. Dana alokasi umum berpengaruh positif terhadap pertumbuhan ekonomi. Hasil ini menunjukkan behwa dengan bertambahnya dana alokasi umum maka akan meningkatkan pertumbuhan ekonomi di Sulawesi Utara. DAU adalah dana yang bersumber dari pendapatan APBN yang dialokasikan dengan tujuan pemerataan kemampuan keuangan antar-daerah untuk mendanai kebutuhan daerah dalam rangka pelaksanaan desentralisasi. Dengan adanya dana alokasi umum maka pertumbuhan ekonomi di Sulawesi Utara akan meningkat.

Meningkatkan pertumbuhan ekonomi melalui dana alokasi umum dilakukan oleh pemerintah daerah diantaranya, bidang pendidikan; seperti pembangunan sekolah. Di bidang kesehatan; untuk dapat meningkatkan jangkauan, dan kualitas pelayanan kesehatan bagi masyarakat, seperti pembangunan rumah sakit, dan puskesmas. Bidang kelautan; pembangunan yang berfokus pada kelautan, penyesuaian dana alokasi umum untuk pembangunan wilayah kepulauan, dan perluasan wewenang pengelolaan otonomi daerah wilayah kepulauan. Pengembangan Sektor Pariwisata dan Industri; Pengembangan Sektor Energi; Ketersediaan energi yang berkesinambungan, handal, terjangkau dan ramah lingkungan merupakan hal yang fundamental dalam membangun industri energi yang bisa mendukung perkembangan ekonomi dan sosial suatu negara. Sehingga masyarakat juga menikmati manfaat dari pembangunan daerah. Tersedianya infrastruktur dapat menciptakan efisiensi dan efektifitas di berbagai sektor produktivitas masyarakat menjadi semakin tinggi dan terjadi peningkatan pertumbuhan ekonomi.

\section{Pengaruh Dana Alokasi Khusus (DAK) terhadap Pertumbuhan Ekonomi}

Hipotesis 3 : Dilihat pada p-value dengan taraf signifikansi sebesar $0,66,5 \%$ yaitu lebih besar dari $\alpha=5 \%$. Menunjukkan bahwa $\mathrm{H}_{1}$ diterima. Mengartikan bahwa Dana Alokasi Khusus tidak berpengaruh terhadap pertumbuhan ekonomi. Setiap kenaikan 1.000.000.000 (satu milyar rupiah) dari DAK akan diikuti oleh penurunan pertumbuhan ekonomi sebesar $-0,00001 \%$. Dengan demikian bahwa DAK tidak berpengaruh terhadap pertumbuhan ekonomi di Sulawesi Utara.

Hal ini disebabkan karena nilai DAK yang diterima pemerintah daerah digunakan untuk mendanai kegiatan khusus yang merupakan urusan daerah. Kegiatan khusus 
yang dimaksud adalah sesuai dengan fungsi yang telah ditetapkan oleh APBN untuk membiayai kebutuhan daerah terpencil, misalnya pembangunan sarana infrastuktur seperti, pelebaran jalan, irigasi, dan air bersih. Dan untuk layanan umum, pendidikan seperti rehabilitasi fisik gedung sekolah/ruang kelas, peningkatan mutu sekolah dengan pembangunan/penyediaan sarana dan prasarana perpustakaan serta fasilitas pendidikan lainnya di sekolah, kesehatan, seperti; Pengadaan peralatan medis dan non medis yang diperuntukkan bagi peningkatan mutu pelayanan kesehatan dasar dan lain-lain. yang berarti tidak boleh disalahgunakan untuk kegiatan diluar ketentuan. Sehingga DAK belum berpengaruh secara langsung terhadap Pertumbuhan Ekonomi.

\section{KESIMPULAN DAN SARAN}

\section{Kesimpulan}

Kesimpulan Berdasarkan hasil pembahasan, maka dapat diambil kesimpulan sebagai berikut :

1 Pendapatan asli daerah signifikan berpengaruh positif terhadap pertumbuhan ekonomi.

2 Dana alokasi umum (DAU) berpengaruh secara signifikan dan berpengaruh positif mengalami peningkatan terhadap pertumbuhan ekonomi di Provinsi Sulawesi Utara.

3 Hasil penelitian menunjukan bahwa tidak terdapat pengaruh positif dan signifikan Dana Alokasi Khusus (DAK) terhadap pertumbuhan ekonomi di Provinsi Sulawesi Utara.

\section{Saran}

1 Pemerintah Sulawesi Utara hendaknya memberi perhatian yang lebih mendalam untuk mereview kriteria Pendapatan Asli Daerah dari sudut pandang kepentingan publik. Penciptaan sumber-sumber PAD baru secara relatif akan lebih baik daripada peningkatan tarif pajak dan dari sumber-sumber penerimaan lainnya. Pengenaan pajak serta retribusi hendaknya tidak semata-mata hanya untuk peningkatan kuantitas PAD tetapi juga memperhatikan keadilan dan kemampuan untuk mencapai pemenuhan kepentingan publik.

2 Pembangunan manusia perlu dilakukan dalam rangka memacu pertumbuhan ekonomi dan mencapai pembangunan ekonomi regional. Untuk itu diperlukan peranan pemerintah daerah dalam mengalokasikan, dan mengawasi dana untuk mendukung pendidikan agar lebih berkualitas dan terarah.

3 Dana Alokasi Khusus harus dialokasikan dengan sasaran dang tujuan yang tepat sehingga tujuan dari kesejahteraan masyarakat dapat tercapai.

\section{DAFTAR PUSTAKA}

---------------, Undang-undang Nomor 33 Tahun 2004 tentang Perimbangan antara Keuangan Pemerintah Pusat dan Pemerintah Daerah.

Badan Pusat Statistik Sulawesi Utara. www.bps.go.id. 2017.

Badan Pusat Statistika Provinsi Sulawesi Utara. 2003 - 2016. Data Pertumbuhan Ekonomi Provinsi Sulawesi Utara.

Brata, 2004. Komposisi Penerimaan Sektor Publik dan Pertumbuhan Ekonomi Regional. Lembaga Penelitian Universitas Atma Jaya Yogyakarta.

Darise. 2008. Akuntansi Keuangan Daerah. Jakarta: PT Indeks.

Halim dan Abdullah., (2004), Akuntansi Keuangan Daerah, Edisi Revisi, Salemba Empat, Jakarta 
Sukirno. S. 2006. Makro Ekonomi Teori

Pengantar. Jakarta : PT Raja Grafindo

Persada 